\title{
EXPLORING GREEN FEATURES THAT MAKE BUILDING MATERIALS GREEN
}

\author{
RATHNAYAKE. P1 ${ }^{1}$, SOORIGE.D ${ }^{2}$, AMARASINGHE S.D.I.A ${ }^{3} \&$ DISSANAYAKE $\mathrm{P}^{4}$ \\ 1, 2,3,4 University of Moratuwa, Moratuwa, \\ prathibharathnayake@gmail.com ${ }^{1}$, dumindu.soorige@gmail.com² ${ }^{2}$ isuriamarasignhe@gmail.com ${ }^{3}$, piumi2d@gmail.com ${ }^{4}$
}

\begin{abstract}
The construction industry plays a significant role in the economic growth of a country. Nevertheless, the construction industry has created severe adverse environmental impacts. Therefore, green building technologies are implemented to alleviate the adverse effects of the construction industry. Using green materials instead of conventional building materials with high environmental impacts has been identified as one such implementation. However, there seems to be much confusion in defining green building materials. Hence, it is vital to explore the features of green building materials. Therefore, this article investigates green features that qualify the building materials as green building materials. A qualitative research approach was selected as the research methodology, and semi-structured interviews were conducted with seven green building experts. The data was analysed using content analysis. Findings revealed that recycled content, local availability of materials, embodied energy of materials, use of rapidly renewable material, usage of waste material for the production process, material wastage content in the production process and pollution prevention in the production process are the green features. The study results guide the identification of green building materials that can replace the materials with poor environmental sustainability.
\end{abstract}

Keywords: Building materials, Construction industry, Green building materials, Green buildings, Sustainability

\section{Introduction}

The construction industry plays a significant role in economic growth by satisfying social needs and increasing the quality of life (Doan et al., 2017). Hence, the construction industry dominates society from the environmental, social, and economic perspectives (Zuo and Zhao, 2014). The construction industry consumes $40 \%$ of total energy, $17 \%$ of water, and emits $35 \%$ of Carbon Dioxide $\left(\mathrm{CO}_{2}\right)$ to the environment (Polat et al., 2017). According to Dwaikat and Ali (2016), the construction industry is a foremost sector for pollution and Greenhouse Gas (GHG) emission and creates negative impacts on the environment.

Stemming from the above facts, governments and environmental organisations have focused on sustainable construction to mitigate adverse impacts (Chan et al 2018). Sustainable construction can mitigate the negative environmental impacts as well as negative social and economic impacts. The buildings, which consume resources such as energy, water, material, and land more efficiently than the other traditional buildings, are called green buildings (Darko et al., 2017). Therefore, green buildings can be identified as a means to achieve sustainability in the construction industry (Chan et al 2018). Green buildings can be explained by referring to the environmental, social, and economic aspects (Zuo and Zhao, 2014). Green buildings reflect energy efficiency, water efficiency, and a lesser carbon emission than conventional buildings (Ali and Nsairat, 2009).

Building materials play a crucial role in achieving the green building concept (Franzoni, 2011). According to modern scientific findings, building materials are the major contributor to indoor pollution (Wanner and Kuhn, 1986). The green buildings utilize low or no Volatile Organic Compound (VOC) materials. Hence, diseases such as nausea, dizziness, headaches, and skin rashes can be prevented by maintaining better indoor air quality using non-VOC green building materials (Tsai, 2018). Traditional 
building materials namely bricks, concrete, stones, cause radioactive pollution, leading to cancers (Meininghaus et al 2000). Furthermore, paints, textile carpets, and glues are considered decorating materials, emitting volatile toxic chemicals into the air (Zhang and Niu, 2003). These emissions cause dry cough, skin diseases, headaches, etc. (Turunen et al 2014). These reactions can be avoided by using green building materials (Sommerhuber et al 2016). Furthermore, the green building materials are recyclable and reusable, and it helps reduce the consumption of natural raw materials for material production $\mathrm{Ng}$ and Chau, 2015). Green building materials can be elaborated as three pillars of sustainability within the purview of the environmental, economic, and social aspects (Li et al 2012). From the environmental perspective, building material production is the primary cause of air pollution (Gall et al 2013) and causes depletion of the ozone layer (Cheng et al 2015). However, low toxicity and lesser chemical emission of green material prevent the emission of hazardous air pollutants (Lamble et al 2011). Therefore, green building materials create less impact on the ozone layer and indirectly cause the improvement of the quality of air (Cheng et al 2015). Also, the ability to recycle with post-consumer material creates a path to mitigate the utilisation of non-renewable resources in the production process (Li, 2008). Reuse and recycling of materials result in good waste management practices without negatively impacting the environment (Amponsah et al 2012). According to the above facts, green materials consume resources more efficiently and can reuse and recycle the materials (Connelly, 2014).

The current construction industry prefers green material rather than traditional material, evolving with the development of the green building concept (Akadiri, 2015). Global environmental pollution has made green building materials a priority. The selection of suitable green material is one of the critical decisions to be taken in designing green buildings since it is necessary to certify as a first-class green building (Franzoni, 2011). The green materials must fulfil requirements according to the national laws, material standards, and code of practices for buildings (Franzoni, 2011). Currently, there seems to be much confusion in defining green building materials where manufacturers tend to qualify their products as green materials. The lack of clear instructions and precise features of green building materials is a challenge to the use of green building materials (Mayhoub et al 2019). Khoshnava et al (2018) conducted a study in Malaysia involving professionals in green building materials to rank green building materials according to the three pillars of sustainable development. The Leadership in Energy and Environmental Design (LEED®) developed by the United States establishes an overall environmental performance standard for the entire building including standards for the following types of green building materials: reused materials, recycled materials, regional materials, rapidly renewable materials, certified wood and lowemission materials (Castro-Lacouture et al 2009). Materials green level would change contextually due to climate and geographical conditions. Still, no evidence has been reported exploring green features of green building materials in the Sri Lankan building sector. Ironically, there is a lack of knowledge and understanding concerning of green features that qualify the building materials as green building materials, especially in the Sri Lankan context. Hence, it is vital to identify green features for qualifying materials as green materials. Therefore, this article attempts to propose green features for green building materials considering various factors that are crucial for sustainable development.

\section{Literature Review}

The following subsections explore the relevant literature in the research arena with a major focus on identifying features of green materials.

\subsection{GREEN FEATURES THAT QUALIFY THE BUILDING MATERIALS AS GREEN BUILDING MATERIALS}

\subsubsection{Recycled content}

Recycling is the process of converting waste into a new product (Hunag et al 2015). The recycling of material can reduce the amount of waste generation and environmental impact associated with raw material extraction and processing (Bolden et al 2013). Recycling can reduce the consumption of raw materials used for the production process. The recycling process consumes less amount of energy. Therefore, recycled materials are economically profitable than new materials (Reddy, 2016). Energy consumption for extracting raw materials can be mitigated through the material recycling process (Reddy, 2016). Steel, bricks, and concrete glass are some of the materials that can be produced through recycling. Further, steel and aluminium can be recycled up to $100 \%$ (Reddy, 2016). According to Saghafi and Teshnizi (2011), the performance of most recyclable materials is similar to or better than the original products. For example, the strength of fly ash brick is higher than the normal clay brick and has lower thermal conductivity than the concrete blocks (Reddy, 2016). In addition, the durability of certain recycled materials is also higher than non-recycled materials. 
Factors that need to be considered when examining the recycling potential of the product include the technology available for recycling, the energy requirement for recycling, demolition techniques, the amount of material required for recycling, and durability of recycling product (Bianchini et al 2005). According to Anderson and Brodin (2005), the recycling method in construction is greatly dependant on the bonding pattern of the material. For example, masonry walls are constructed by using bricks combined with mortar. It is difficult to dismantle and separate the bricks apart, nor could it be reused. Therefore, it can be used for roads as coarse aggregate after recycling (Anderson and Brodin, 2005). The recycling process can be improved by implementing new technology during demolition (Suttibak and Nitivattananon, 2008). Table 1 emphasises the uses of recycled materials in the construction industry.

\begin{tabular}{|l|l|}
\hline Recycled material & Usage in the Construction Industry \\
\hline Aggregate & Hardcore filling for foundation and filling for drainage line \\
\hline Excavated material & For filling \\
\hline Pulverised fuel ash & $\begin{array}{l}\text { To manufacture concrete and as a filling material for reinforced } \\
\text { soil structures }\end{array}$ \\
\hline Metal & To manufacture new metals \\
\hline Glass & $\begin{array}{l}\text { Substitute for sand and aggregate as pipe bedding material and } \\
\text { gravel backfill for wall }\end{array}$ \\
\hline Plastic & Synthetic material in the form of lumber for landscape \\
\hline Rubber & To manufacture rubber slate tile in roof \\
\hline Expanded polystyrene & To manufacture lightweight concrete for non-structural works \\
\hline Slag & Used as concrete mixtures and as a soil stabiliser \\
\hline
\end{tabular}

Table 1: Use of Recycled Materials in the Construction Industry Source: (Tam and Tam, 2006)

Therefore, considering the importance of the recycled content, it can be identified as green feature that qualify the building materials as green building materials.

\subsubsection{Reusability of building materials}

Previously used components of the building can be used in various ways, namely adaptive reuse, relocation, and component reuse (Yuksek and Esin, 2013). Reuse of existing whole structure is called adaptive reuse (Misırlısoya and Günce, 2016). Also, reuse techniques adapted while moving the existing building to another place is called relocation (da Rocha and Sattler, 2009). Reusing individual components of the demolished building is called component reuse (Gorgolewski, 2008). Structural components such as beams, columns, doors, and windows and non-structural components such as bricks and panels can be reused to the maximum. Reusing the building components reduces the environmental impact in various ways, such as in recycling (Yu and Shui, 2014). Reuse of building material is also environmentally friendly due to the reduction of the usage of a non-renewable resource. Further, reuse can be identified as an alternative solution to construction waste disposal (Charytonowicz and Skowronski, 2015). Also, reuse of building components is economically and environmentally beneficial than recycling (Yu and Shui, 2014). Therefore, reusable building materials are considered green in the construction industry (Yung and Chan, 2012). However, reuse cannot be adapted with some materials. For example, in situ concrete can be damaged in the demolition process (Afify and Soliman, 2014). The material's embodied energy is the foremost factor in deciding on the suitability of that material either for reuse or recycling (Fuertes, 2017). According to this, processed components of high value, such as metal, plastics, bricks are better for reuse (Amponsah et al 2012). Table 2 provides examples of reusable and recyclable materials.

\begin{tabular}{|l|l|l|l|}
\hline \multicolumn{1}{|c|}{ Item } & \multicolumn{1}{|c|}{ What to reuse } & \multicolumn{1}{c|}{ What to recycle } & \multicolumn{1}{c|}{ What to dispose } \\
\hline $\begin{array}{l}\text { Wood (lumber, } \\
\text { flooring, etc.) }\end{array}$ & $\begin{array}{l}\text { Timbers, large dimension lumber, } \\
\text { plywood, flooring, } \\
\text { moulding, lumber longer than 6 } \\
\text { feet }\end{array}$ & $\begin{array}{l}\text { Unpainted and untreated } \\
\text { wood unfit for reuse }\end{array}$ & $\begin{array}{l}\text { Painted, pressure } \\
\text { treated and rotting } \\
\text { wood }\end{array}$ \\
\hline Windows & $\begin{array}{l}\text { Windows in good condition (for } \\
\text { single panes, consider adding } \\
\text { storm windows) }\end{array}$ & $\begin{array}{l}\text { Metal frames and } \\
\text { screens, unpainted and } \\
\text { untreated wood }\end{array}$ & $\begin{array}{l}\text { Unusable } \\
\text { painted items }\end{array}$ \\
\hline $\begin{array}{l}\text { Plumbing } \\
\text { products }\end{array}$ & Sinks, tubs, faucets & $\begin{array}{l}\text { Metal pipe, toilet inefficient } \\
\text { plumbing fixtures }\end{array}$ & \\
\hline
\end{tabular}




\begin{tabular}{|l|l|l|l|}
\hline Electrical products & $\begin{array}{l}\text { Electrical products in good } \\
\text { working order }\end{array}$ & Metal fixture and conduit & $\begin{array}{l}\text { Ceramic and plastic } \\
\text { parts }\end{array}$ \\
\hline Roofing materials & Sheeting in good condition & $\begin{array}{l}\text { Metal materials, asphalt } \\
\text { roofing materials }\end{array}$ & Treated cedar sheeting \\
\hline
\end{tabular}

Table 2: Reusable and recyclable materials

Source: (Gifford and Ducharme, 2012)

\subsubsection{Rapidly renewable materials}

Rapidly renewable materials can be identified as materials that are plant-based and they regenerate within 10 years or less (Agoudjil et al 2011). Renewable resources should be utilised for renewable material production (Raquez et al 2010). Wind energy, marine energy, solar energy, hydro energy, geothermal energy, and bioenergy are the main renewable energy sources for material production (Ellabban et al 2014).

Hemp, timber, and bamboo are some renewable natural materials used for building construction (Crocker, 2008). Renewable material generating percentages vary from material to material (Chung and $\mathrm{Yu}, 2002)$. Further, oak and bamboo are considered as specimens for the natural renewable material, where bamboo matures more than oak (Chung and $\mathrm{Yu}, 2002$ ). The author specifies that bamboo matures within 2-3 years but oak takes approximately six years. Therefore, according to Ellabban et al (2014), the material generating percentage is a crucial point when selecting renewable materials, as alternatives. Raw materials used in these productions are abundant and biodegradable (Agoudjil et al 2011). Further rapidly renewable materials are a good solution for the conservation of natural resources. Therefore, rapidly renewable materials become green materials for building construction (Mehta et al 2014).

According to section 2.1 following are features of green materials

- The recycled content

- Reusability building material and its component

- Rapidly renewable materials

Recently, a considerable amount of research work has been committed towards green materials. Comparatively, less effort has been applied towards the exploration of the features of green materials in Sri Lanka. Such explorations can set the research agenda for the future. In this sense, an academic gap exists in recognising features of green materials. Therefore, in the context of Sri Lanka, the investigation of features of green materials will be a timely research topic. The research methodology of the study is discussed next.

\section{Research Method}

Lichtman (2010) emphasised that qualitative research methods are used to obtain a deeper understanding of specific areas by investigating the knowledge and experience of experts. Qualitative research involves collecting and analysing non-numerical data to understand concepts, opinions, or experiences. According to Easterby-Smith, Thorpe and Lowe (2002), there are several advantages of selecting the qualitative research approach such as focus on in-depth study on broad topics, and representation of the perspectives of a specific set of people. This research deals with qualitative information in achieving answers for the research question by exploring the features of green building materials. Hence, a qualitative research approach has been selected. Expert interviews have been selected as the data collection technique of this research. Punch (2013) explained the appropriateness of the expert interview for the qualitative approach which is commonly used. Further, according to Punch (2013), three types of expert interviews can be identified such as structured, semi-structured, and unstructured interviews. In an unstructured interview, interviewees provide opinions freely when asked open-ended questions by the interviewer. In the case of a structured interview, predominant questions are used by the interviewer (Dawson, 2002) which is more towards a quantitative approach. The semi-structured interviews were selected for this research because of the suitability of the structure of semi-structured interviews and the ability to explore the area based on the existing literature. Accordingly, the semi-structured interviews were conducted using seven green building experts in the construction industry in Sri Lanka to discover relevant data. Interviewees for the study were selected by considering several factors such as relevancy to the research field and their experience. Details of the interviewees are illustrated in Table 3. Interview guideline was developed based on the literature findings. 


\begin{tabular}{|l|l|l|c|c|}
\hline Detail & Profession & Designation & Organisation type & Experience \\
\hline Expert 1 (EX1) & Engineer & Director & Consulting & 18 years \\
\hline Expert 2 (EX2) & Engineer & Director & Consulting & 15 years \\
\hline Expert 3 (EX3) & Engineer & Director & Consulting & 12 years \\
\hline Expert 4 (EX4) & Engineer & Director & Consulting & 15 years \\
\hline Expert 5 (EX5) & Architect & Director & Consulting & 20 years \\
\hline Expert 6 (EX6) & Engineer & $\begin{array}{l}\text { Sustainability } \\
\text { Engineer }\end{array}$ & Contractor & 10 years \\
\hline Expert 7 (EX7) & Engineer & Engineer & Contractor & 12 years \\
\hline
\end{tabular}

Table 3: Details of the interviewees

\section{Research Findings and Discussion}

The findings present the development of the features of green building materials. This includes features such as recycled content, use of rapidly renewable material for the production process, local availability of materials, reuse of materials, embodied energy of materials, usage of waste material for the production process, material wastage content in the production process and pollution prevention in the production process.

\subsection{FEATURES FOR QUALIFYING MATERIALS AS GREEN BUILDING MATERIALS}

\section{- $\quad$ Recycled Content}

According to experts, recycling of construction materials helps to mitigate the amount of construction waste and environmental impacts associated with them. EX1 stated, "recyclable material utilisation for the production process is one of the foremost actions to mitigate the construction waste". This is confirmed in the literature findings of (Bolden et al 2013). Further, EX5 argues that recycled material utilisation causes a reduction in the embodied energy of the product. The above argument is broadly described in the literature review as a reduction of the energy consumption for extracting raw materials by recycling (Reddy, 2016). Moreover, the EX4 emphasises that the "efficiency of the recycling process can be improved through the utilisation of new technologies and it caused to change the embodied energy of the materials". EX2, EX3, EX6, and EX7 also expressed that the recycled content can be identified as feature of green materials which confirm the literature findings.

- Use of rapidly renewable material for the production process

EX7 illustrates that the greenness of the rapidly renewable materials depends on the time consumes for the process of regeneration. The same thing has been elucidated in the literature, through an example that comparing oak and bamboo. The bamboo takes 2-3 years to mature, whereas the oak takes 6-7 years. (Chung and $\mathrm{Yu}, 2002$ ). Hence, it is better to use bamboo as a green material for construction rather than oak. As far as EX2 and EX3 are concerned, the major objective of utilising renewable materials is to reduce the depletion of non-renewable materials. Meanwhile, EX5 illustrates that rapidly renewable material utilisation will be triggered when protecting the balance of the ecosystem. Similarly, environmental equilibrium can be maintained without much disruption. Further, EX1 emphasises that rapidly renewable material utilisation will save raw materials for future generation. Similarly, EX4, EX6 also accepts the use of rapidly renewable material for the production process. Therefore, both empirical findings and the literature confirms the rapidly renewable material as a feature of green materials.

- $\quad$ Reuse of materials

According to literature findings, reuse of the building and its component can be categorised into three levels as adaptive reuse, relocation, and component reuse. EX6 explains that the embodied energy can be changed with the reuse method. EX2 and EX5 argue that the reused materials become environmentally friendly due to the mitigation of GHG emissions, providing a solution to construction waste mitigation, and protecting non-renewable resources. All interviewees and the literature agreed that the reuse of materials can be used as a feature of green materials.

- $\quad$ Locally availability of materials 
EX4 emphasises that the major objective of the utilisation of locally available construction materials is to "reduce the energy consumption for transportation process and it reduces the embodied energy of the final materials". On the other hand, EX7 elaborates that "GHG emission reduction is an indirect positive environmental effect of the utilisation of locally available materials". Carbon Dioxide (CO2), Carbon Monoxide (CO), and Nitric Oxide (NO) can be identified as GHG that are emitted during the transportation process. Those GHG emissions create negative environmental impacts namely increased global warming, damage to the ozone layer, and increased sea levels due to the melting of glaciers. Therefore, utilisation of locally available materials helps to reduce such negative impacts. EX1 further explains that the greenness value of the material increases due to the reduction of GHG emissions during transportation. Hence, the greenness of the material will depend on the distance between the construction site and the manufacturing location. EX2 further elaborates the consequences for the environment when the raw materials are not available locally. Then, the materials should be imported from another country with high environmental impacts related to international transportation. Meanwhile, EX3, EX5, and EX6 also accept the above factor as a green feature that qualify the building materials as green building materials.

\section{- Embodied energy of materials}

According to EX5 "embodied energy is the energy consumed by the material in the process associated with the production of material including raw material extraction to deliver to the site, but not including the operational and disposal stages of materials". Every building is a complex combination of many processed materials, each of which contributes to the building's total embodied energy. The embodied energy is highlighted as the key area which should be addressed to reduce $\mathrm{CO}_{2}$ emission. Meanwhile, EX1 argues that the highly processed material includes high embodied energy. As mentioned previously, locally available materials and natural materials contain less embodied energy. EX6 further elaborates, "embodied energy measurement is the best method to identify the material as green". The EX2 and EX3 also accept this above factor as a green feature that qualify the building materials as green building materials

- Usage of waste material for the production process

Most of the waste materials create negative impacts on the environment in the disposal stage. As an example, earth slips may occur due to non-crumbling material such as plastic. Utilisation of such materials to another production will decrease the environmental impacts associated with them. Moreover, the problems associated with disposal can be overcome by this method. EX1 also argues that heavy metal discharge to the environment during the disposal stage could also be mitigated through waste material utilisation for another production process. EX3 elaborates that utilisation of waste materials for the production process leads to reserve the natural resources. Similarly, EX4 argues that the use of waste materials causes a reduction in the embodied energy of the material due to a lesser amount of workmanship in extracting raw materials. Therefore, the waste material utilisation for the production process may lead to creating direct and indirect positive environmental impacts. Hence, the use of waste material for production can be identified as a feature that qualify the building materials as green building materials.

- Material wastage content in the production process

According to the argument of EX4, material wastage content within the production process is an important fact when considering the greenness of the materials. EX4 elaborates that raw material consumption can be mitigated with a waste reduction during the production process. EX1 mentions that GHG emissions can be mitigated with a waste reduction during the production process. Simultaneously EX2 highlights that the waste management process will be simplified when satisfying the above factor. Further, EX5 and EX7 also accept above feature that qualify the building materials as green building materials.

- Pollution prevention in the production process

According to EX7 pollution prevention within the production process leads to increase greenness of materials. According to EX5 air, water and land are the major areas for consideration and discussed under pollution prevention. EX3 also elaborates that GHG emission reduction is the foremost factor encountered for the prevention of air pollution. Apart from this dust minimisation is also encountered under air pollution prevention. EX6 mentions that waste mitigation and renewable energy consumption will lead to pollution prevention. All interviewees accepted this as a green feature that qualify the building materials as green building materials. A summary of section 4.1 is depicted in Figure 1. 


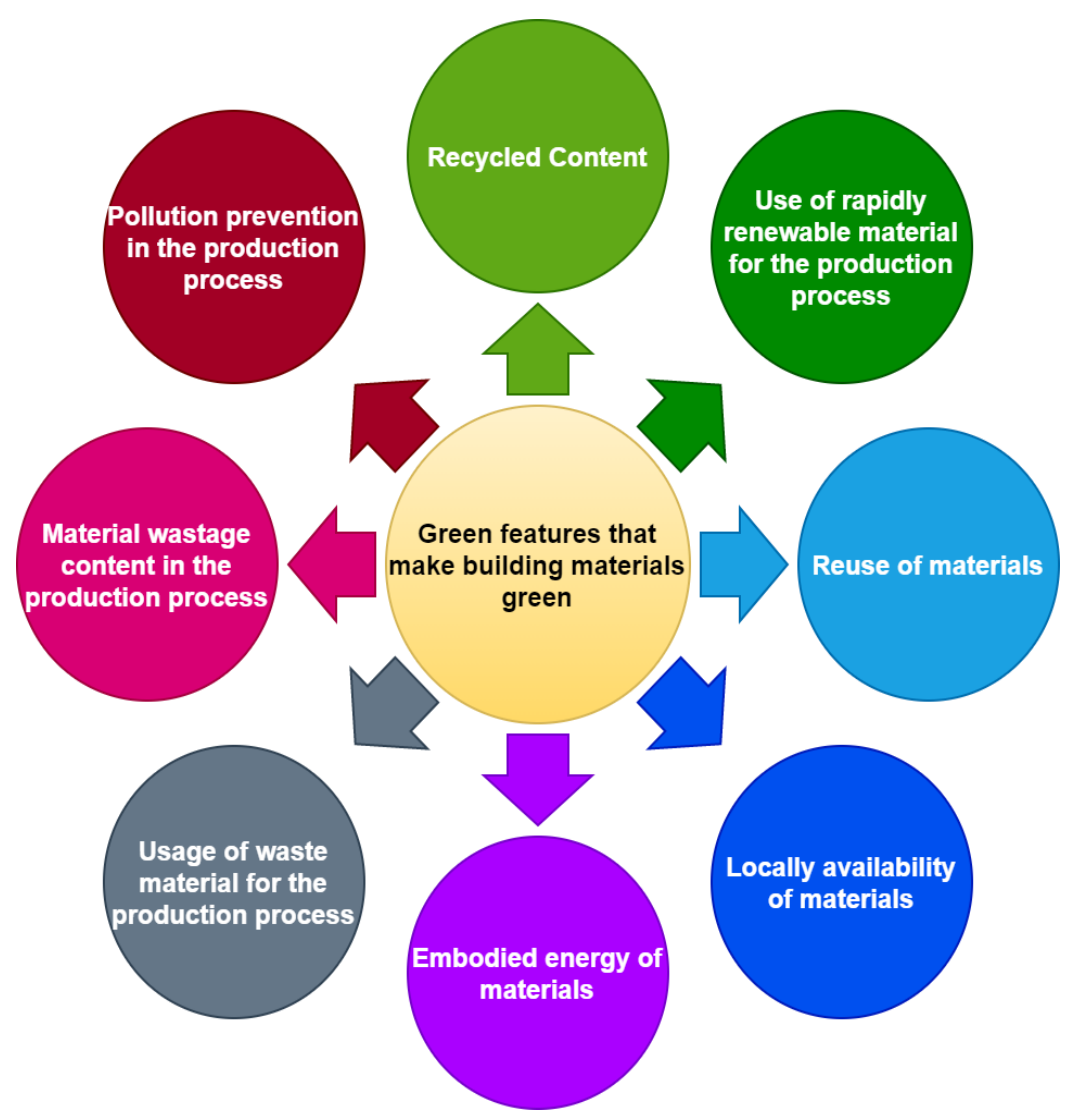

Figure 1, Summary of the green features that qualify the building materials as green building materials

\section{Conclusions}

This article attempts to propose features for qualifying materials as green building materials. According to the literature, recyclability of the materials, reusability of the materials, and use of the rapidly renewable raw material are considered as the green features that qualify the building materials as green building materials. The empirical investigation confirmed the features identified in the literature and further added, local availability of materials, embodied energy of materials, usage of waste material for the production process, material wastage content in the production process, and pollution prevention in the production process as green features. Overall, this study has explored more features in addition to the literature.

The findings of this study will provide better opportunities to increase the environmental performance of their building products for building material manufactures. Further, this study will enable the project executors with the evaluation of the greenness of building materials to implement sustainable construction practices. The results also provide a valuable reference for building professionals to improve sustainable construction through green materials. Further research can be carried out to rate the identified green features based on its importance using different weightages.

\section{References}

Afify, M.R. and Soliman, N.M., 2014. Improvement properties of recycle concrete using clay brick as a coarse aggregate. International Journal of Current Engineering and Technology, 4(1), pp.119-127.

Agoudjil, B., Benchabane, A., Boudenne, A., Ibos, L. and Fois, M., 2011. Renewable materials to reduce building heat loss: Characterisation of date palm wood. Energy and buildings, 43(2-3), pp.491497.

Akadiri, P.O., Chinyio, E.A. and Olomolaiye, P.O., 2012. Design of a sustainable building: A conceptual framework for implementing sustainability in the building sector. Buildings, 2(2), pp.126-152.

Ali, H.H. and Al Nsairat, S.F., 2009. Developing a green building assessment tool for developing countriesCase of Jordan. Building and environment, 44(5), pp.1053-1064. 
Amponsah, N.Y., Lacarrière, B., Jamali-Zghal, N. and Le Corre, O., 2012. Impact of building material recycle or reuse on selected emergy ratios. Resources, conservation and recycling, 67, pp.9-17.

Anderson, H. and Brodin, M.H., 2005. The consumer's changing role: the case of recycling. Management of Environmental Quality: An International Journal.

Bianchini, G., Marrocchino, E., Tassinari, R. and Vaccaro, C., 2005. Recycling of construction and demolition waste materials: a chemical-mineralogical appraisal. Waste Management, 25(2), pp.149-159.

Bolden, J., Abu-Lebdeh, T. and Fini, E., 2013. Utilisation of recycled and waste materials in various construction applications. American Journal of Environmental Science, 9(1), pp.14-24.

Castro-Lacouture, D., Sefair, J.A., Flórez, L. and Medaglia, A.L., 2009. Optimisation model for the selection of materials using a LEED-based green building rating system in Colombia. Building and environment, 44(6), pp.1162-1170.

Charytonowicz, J. and Skowroński, M., 2015. Reuse of building materials. Procedia Manufacturing, 3, pp.1633-1637.

Cheng, Y.H., Lin, C.C. and Hsu, S.C., 2015. Comparison of conventional and green building materials in respect of VOC emissions and ozone impact on secondary carbonyl emissions. Building and Environment, 87, pp.274-282.

Chung, K.F. and Yu, W.K., 2002. Mechanical properties of structural bamboo for bamboo scaffoldings. Engineering structures, 24(4), pp.429-442.

Connelly, M.C., 2014. Innovation compared with materials production: current trends in green energy production and materials. Current Opinion in Chemical Engineering, 3, pp.125-129.

Crocker, J., 2008. Natural materials. Materials technology, 23(3), pp.174-178.

da Rocha, C.G. and Sattler, M.A., 2009. A discussion on the reuse of building components in Brazil: an analysis of major social, economical and legal factors. Resources, Conservation and Recycling, 54(2), pp.104-112.

Darko, A., Zhang, C. and Chan, A.P., 2017. Drivers for green building: A review of empirical studies. Habitat international, 60, pp.34-49.

Doan, D.T., Ghaffarianhoseini, A., Naismith, N., Zhang, T., Ghaffarianhoseini, A. and Tookey, J., 2017. A critical comparison of green building rating systems. Building and Environment, 123, pp.243-260.

Dwaikat, L.N. and Ali, K.N., 2016. Green buildings cost premium: A review of empirical evidence. Energy and Buildings, 110, pp.396-403.

Easterby-Smith, M., Thorpe, R. and Lowe, A., 2002. 2nd. Management Research: An Introduction. London, Sage Publications.

Ellabban, O., Abu-Rub, H. and Blaabjerg, F., 2014. Renewable energy resources: Current status, future prospects and their enabling technology. Renewable and Sustainable Energy Reviews, 39, pp.748764.

Esin, T. and Yüksek, İ., 2013. Sustainable resource utilisation in the production of building materials. International Journal of Sustainable Building Technology and Urban Development, 4(2), pp.141-145.

Franzoni, E., 2011. Materials selection for green buildings: which tools for engineers and architects?. Procedia Engineering, 21, pp.883-890.

Fuertes, P., 2017. Embodied energy policies to reuse existing buildings. Energy procedia, 115, pp.431-439.

Gall, E., Darling, E., Siegel, J.A., Morrison, G.C. and Corsi, R.L., 2013. Evaluation of three common green building materials for ozone removal, and primary and secondary emissions of aldehydes. Atmospheric Environment, 77, pp.910-918.

Gorgolewski, M., 2008. Designing with reused building components: some challenges. Building Research \& Information, 36(2), pp.175-188.

Hunag, L.J., Wang, H.Y. and Wang, S.Y., 2015. A study of the durability of recycled green building materials in lightweight aggregate concrete. Construction and building Materials, 96, pp.353-359.

Khoshnava, S.M., Rostami, R., Valipour, A., Ismail, M. and Rahmat, A.R., 2018. Rank of green building material criteria based on the three pillars of sustainability using the hybrid multi criteria decision making method. Journal of Cleaner Production, 173, pp.82-99.

Lamble, S.P., Corsi, R.L. and Morrison, G.C., 2011. Ozone deposition velocities, reaction probabilities and product yields for green building materials. Atmospheric environment, 45(38), pp.6965-6972. 
Li, L., Wang, P., Wang, H. and Zhang, M., 2012. Green building materials evaluation and empirical research based on the regional endowment. AASRI Procedia, 3, pp.381-386.

$\mathrm{Li}, \mathrm{X} ., 2008$. Recycling and reuse of waste concrete in China: Part I. Material behaviour of recycled aggregate concrete. Resources, Conservation and Recycling, 53(1-2), pp.36-44.

Lichtman, M., 2010. Understanding and evaluating qualitative educational research. Sage Publications.

Mayhoub, M.M.G., Ibrahim, M.G., El Sayad, Z.M.T. and Ali, A.A.M.M., 2019, October. Development of green building materials' evaluation criteria to achieve optimum building facade energy performance. In 2019 International Conference on Sustainable Energy Engineering and Application (ICSEEA) (pp. 1-8). IEEE.

Mehta, G., Mehta, A. and Sharma, B., 2014. Selection of materials for green construction: A review. Journal of Mechanical and Civil Engineering, 11(6), pp.80-83.

Meininghaus, R., Gunnarsen, L. and Knudsen, H.N., 2000. Diffusion and sorption of volatile organic compounds in building materials- Impact on indoor air quality. Environmental Science \& Technology, 34(15), pp.3101-3108.

Mısırlısoy, D. and Günçe, K., 2016. Adaptive reuse strategies for heritage buildings: A holistic approach. Sustainable Cities and Society, 26, pp.91-98.

Ng, W.Y. and Chau, C.K., 2015. New life of the building materials-recycle, reuse and recovery. Energy Procedia, 75, pp.2884-2891.

Polat, G., Turkoglu, H. and Gurgun, A.P., 2017. Identification of material-related risks in green buildings. Procedia engineering, 196, pp.956-963.

Punch, K.F., 2013. Introduction to social research: Quantitative and qualitative approaches. sage.

Raquez, J.M., Deléglise, M., Lacrampe, M.F. and Krawczak, P., 2010. Thermosetting (bio) materials derived from renewable resources: A critical review. Progress in polymer science, 35(4), pp.487-509.

Saghafi, M.D. and Teshnizi, Z.S.H., 2011. Recycling value of building materials in building assessment systems. Energy and Buildings, 43(11), pp.3181-3188.

Sommerhuber, P.F., Wenker, J.L., Rüter, S. and Krause, A., 2017. Life cycle assessment of wood-plastic composites: Analysing alternative materials and identifying an environmental sound end-of-life option. Resources, Conservation and Recycling, 117, pp.235-248.

Suttibak, S. and Nitivattananon, V., 2008. Assessment of factors influencing the performance of solid waste recycling programs. Resources, Conservation and Recycling, 53(1-2), pp.45-56.

Tam, V.W. and Tam, C.M., 2006. Evaluations of existing waste recycling methods: a Hong Kong study. Building and Environment, 41(12), pp.1649-1660.

Tsai, W.T., 2018. Overview of green building material (GBM) policies and guidelines with relevance to indoor air quality management in Taiwan. Environments, 5(1), p.4.

Turunen, M., Toyinbo, O., Putus, T., Nevalainen, A., Shaughnessy, R. and Haverinen-Shaughnessy, U., 2014. Indoor environmental quality in school buildings, and the health and wellbeing of students. International journal of hygiene and environmental health, 217(7), pp.733-739.

Wanner, H.U. and Kuhn, M., 1986. Indoor air pollution by building materials. Environment International, 12(1-4), pp.311-315.

Zhang, L.Z. and Niu, J.L., 2003. Mass transfer of volatile organic compounds from painting material in a standard field and laboratory emission cell. International Journal of Heat and Mass Transfer, 46(13), pp.2415-2423.

Zuo, J. and Zhao, Z.Y., 2014. Green building research-current status and future agenda: A review. Renewable and sustainable energy reviews, 30, pp.271-281. 